\title{
The chemical defences of the invasive alga Sargassum muticum (Yendo) Fensholt correlate to mesoherbivore diversity, but not to time-since-invasion
}

\author{
Martyn Kurr $\mathbb{D} \cdot$ Andrew J. Davies
}

Received: 3 December 2018/Revised: 13 February 2019/Accepted: 19 March 2019/Published online: 27 March 2019

(C) The Author(s) 2019

\begin{abstract}
Populations of the invasive alga Sargassum muticum were sampled along a time-sinceinvasion (TSI) gradient to test the hypothesis that chemical defences would increase with TSI, and diversity of native mesoherbivores. Algal chemical defences, phlorotannins, were quantified as a proxy for top-down-pressure, and these were compared with both native enemy diversity and time-since-invasion at each of seven sites along the west coast of the UK. The defences in the annual fronds showed a strong positive correlation with the biodiversity of native mesoherbivores. The defences in the perennial holdfasts, whilst generally higher than those in the fronds,
\end{abstract}

Handling editor: Jonne Kotta

Electronic supplementary material The online version of this article (https://doi.org/10.1007/s10750-019-3939-2) contains supplementary material, which is available to authorized users.

M. Kurr $(\bowtie)$ - A. J. Davies

School of Ocean Sciences, Bangor University,

Menai Bridge LL59 5AB, UK

e-mail: martyn.kurr@ncl.ac.uk

Present Address:

M. Kurr

School of Marine Science and Technology, Newcastle University, Newcastle upon Tyne NE1 7RU, UK

\section{A. J. Davies}

Department of Biological Sciences, University of Rhode Island, Kingston, RI 02881, USA showed no relationship. In contrast, defences in neither the fronds nor the holdfasts showed any relationship with TSI. The majority of mesoherbivores found in this survey were small and probably juvenile. Many of these individuals are known to occupy the fronds of $S$. muticum for shelter or to feed on its epiphytes, and are probably less likely to feed directly on its tissues than adults. The low probability that any one species of grazer was feeding on S. muticum tissues may explain why the alga contained a greater level of phlorotannin when the diversity of potential enemies was high. This study highlights the importance of enemy diversity in invasion ecology.

Keywords Algal ecology · Biological invasions . Chemical ecology $\cdot$ Herbivory

\section{Introduction}

The ecology of non-native plants has received considerable investigative effort to date, and a number of theories exist to explain the specific trends associated with their introduction (Keane \& Crawley, 2002; Levine et al., 2004; Lind \& Parker, 2010). Recently, the fundamentals of well-tested conceptual models such as the Biotic Resistance Hypothesis and the Enemy Release Hypothesis have been distilled into the concept of 'Eco-Evolutionary Experience' (Saul et al., 
2013). This model posits that if an invasive species is equipped with adaptations to cope with biotic pressures in its new range, but the native community is not equipped to cope with the invader, the invasive species should spread, and vice versa. Conversely, both invasive and native species may possess adaptations suited to cope with one another, or neither may possess these adaptations. In these latter scenarios, it is often unclear whether the native or non-native fractions of the community will become dominant (Saul \& Jeschke, 2015).

Regions of high native controphic species diversity are often assumed to have the greatest resistance to invasion by non-natives. However, there is evidence to suggest that the most diverse communities may be the most invaded (e.g. Stohlgren et al., 1999; Levine, 2000; Thomas \& Palmer, 2015), and even that diversity and invasibility may be disconnected in some cases (Sun et al., 2015). It could be argued that a better predictor of biotic pressure experienced by non-natives is enemy diversity. A non-native plant does not come under attack by every species of native grazer, and so the greater the diversity of herbivores the greater the probability of attack (Agrawal et al., 2005). This is possibly because of the greater abundance of generalist grazers in diverse, stronglyinterconnected food-webs, which are the least susceptible to invasion (Smith-Ramesh et al., 2017). Diversity of native enemies is particularly important to marine algal invaders; whilst marine consumers impart similar levels of biotic resistance to terrestrial consumers, marine producers often impart less resistance than their terrestrial counterparts (Kimbro et al., 2013).

Although less well-studied, the impact of timesince-invasion (TSI) is also a modifying factor in the pressure experienced by non-natives in newly occupied ranges. The longer a non-native species has been present in a given region, the greater the length of time native enemies will have had to adapt to its presence. Theoretically this should increase the top-down pressure the non-native experiences (Saul \& Jeschke, 2015). This shift may impede and even reverse the dominance of a successful invader (Dostál et al., 2013), although proxies for top-down pressure experienced by the non-native may increase or decrease depending on the metric assessed. For example, whilst 'diversity of associated herbivores' may increase, 'leaf damage' may actually decrease over time (Harvey et al., 2013), making it important to carefully consider methodology when assessing top-down-pressure, and especially when comparing between studies.

The invasive alga Sargassum muticum Yendo (Fensholt) originates from the Sea of Japan, and has progressively spread throughout Europe and North America (Davison, 2009; Mineur et al., 2010; Engelen et al., 2015). It is a member of the order Fucales, which are well-represented in European and North American waters (Rousseau et al., 1997). Like other Fucales, it produces phlorotannins as a chemical deterrent to herbivores (Engelen et al., 2015). However, native grazers typically ignore it in feeding trials, preferring to consume native algal species (e.g. Norton \& Benson, 1983; Critchley et al., 1986; Monteiro et al., 2009; Cacabelos et al., 2010a; Engelen et al., 2011; Schwartz et al., 2016) unless the grazers are highly generalist and presented with particularly tough or well-defended native algae (Pedersen et al., 2005; Strong et al., 2009), or have been exposed to $S$. muticum for many generations (Kurr \& Davies, 2017a). The lack of interest native herbivores show in S. muticum is unusual because, according to the ecoevolutionary concept, most of these species should possess the necessary adaptations to consume $S$. muticum due to the presence of similar defences in native algae (Engelen et al., 2015).

Although $S$. muticum is not usually consumed by large herbivores such as fish and urchins (but see Pedersen et al., 2005), it does attract a range of mesoherbivores (small crustaceans and gastropods) that are equally as diverse as those found on nearby native algae (Withers et al., 1975; Norton \& Benson, 1983; Van Alstyne \& Paul, 1990; Viejo, 1999; Wernberg et al., 2004; Thomsen et al., 2006; Strong et al., 2009; Cacabelos et al., 2010b; Engelen et al., 2013) provided their fractal complexity is similar (Veiga et al., 2014; Veiga et al., 2018; and see Dijkstra et al., 2017). In contrast to large herbivores that can eat whole macrophytes at once, even closely-related mesoherbivores can impart very different top-down pressures due to their broad range of feeding-modes and foraging preferences (e.g. Pavia et al., 1999; Karez et al., 2000; Pavia \& Toth, 2000; Lankau, 2007). For example, small swimming crustaceans are perhaps better adapted to feed on $S$. muticum than gastropods, because the light and feathery fronds of $S$. muticum provide limited sites for attachment of a gastropod foot. Gastropods often concentrate their feeding on the 
holdfast-regions of other algae (e.g. Watson \& Norton, 1987; Davies et al., 2007), which are usually thicker than the fronds and move less with the action of waves. Likewise, many grazers could be feeding principally on the epiphytes of S. muticum (Viejo, 1999; Cacabelos et al., 2010b) or exploiting its fronds for shelter (e.g. Machado et al., 2015). Surprisingly few studies include diversity of local grazers when examining the impacts on invasive plants and algae (Kimbro et al., 2013), and little is known about how grazer diversity might impact a species such as $S$. muticum.

The top-down-pressure on a plant or alga will depend on the foraging preferences of the grazers it hosts (e.g. Enge et al., 2013) and it is possible that native grazers need time to adapt to $S$. muticum and begin to consume it. Local-scale selection determines the feeding preferences of many marine mesoherbivores (Sotka, 2005), which may be ingrained postpartum (Vesakoski et al., 2009; Mattila et al., 2014) meaning that shifts in preference may take several generations to occur. Time-since-invasion is an understudied approach in ecology, and historically very few researchers have specifically incorporated it into tested hypotheses (discussed by Strayer et al., 2006). However, there is evidence to suggest that grazers from long-established stands of S. muticum are more likely to consume it than those from recentlyestablished stands (Kurr \& Davies, 2017a). It remains unclear if the increased grazer preference shown in the laboratory manifests as increased top-down pressure in the field, and whether time-since-invasion is more or less important to top-down pressure on S. muticum than enemy diversity.

This study aimed to further understanding of the invasive ecology of $S$. muticum, by determining the importance of grazer diversity and the length of time grazers have been exposed to the alga, on top-down pressure experienced by it. Direct grazing pressure reduces the palatability of $S$. muticum-almost certainly via the induction of phlorotannins (Pavia \& Toth, 2008) - although waterborne cues do not (Toth, 2007). This makes phlorotannin abundance a useful proxy for top-down-pressure in this species. By measuring phlorotannin abundance in both the fronds and the holdfasts, and conducting mesoherbivore surveys in seven discrete stands of known timesince-invasion, two hypotheses are tested: (1) Phlorotannin abundance in S. muticum will be positively dependent on the diversity of grazers associated with its stand, and (2) Phlorotannin abundance in $S$. muticum will be positively dependent on the timesince-invasion of its stands.

\section{Materials and methods}

Sample sites

Seven populations of $S$. muticum were surveyed around the UK based on their estimated time-sinceinvasion (Critchley et al., 1983; Davison, 2009; Fig. 1). S. muticum is ideally suited to a time-sinceinvasion approach, as two studies have demonstrated that the species expresses limited DNA polymorphism within UK and European populations (Hallas, 2012;

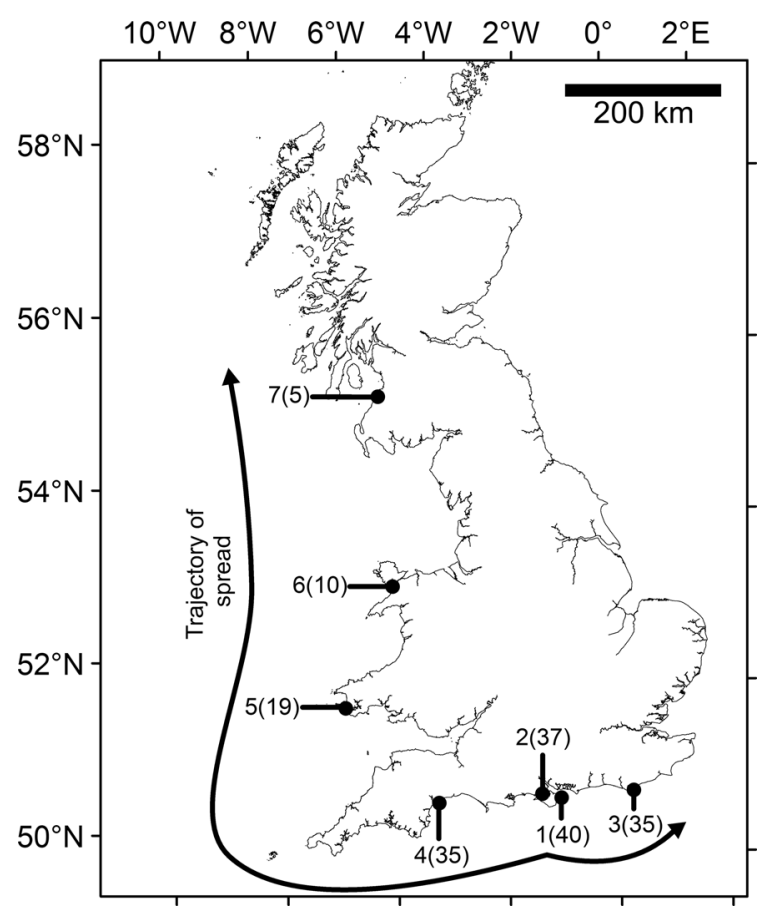

Fig. 1 Locations of Sargassum muticum populations sampled for algal material and mesoherbivores. Sites are named by the time-since-invasion of S. muticum (years in parentheses) and the arrows show the trajectory of spread from the first known observation at Bembridge Ledge. Sites are as follows: 1(40) Bembridge Ledge $\left(50.680466^{\circ} \mathrm{N}, 1.072554^{\circ} \mathrm{W}\right)$. 2(37): Lepe $\left(50.783981^{\circ} \mathrm{N}, 1.355657^{\circ} \mathrm{W}\right) .3(35)$ : Eastbourne $\left(50.750541^{\circ} \mathrm{N}\right.$, $\left.0.270442^{\circ} \mathrm{E}\right) .4(35)$ : Sandy Bay, near Exmouth $\left(50.607876^{\circ} \mathrm{N}\right.$, $\left.3.363291^{\circ} \mathrm{W}\right)$. 5(19): West Angle Bay, near Milford Haven $\left(51.688676^{\circ} \mathrm{N}, 5.110854^{\circ} \mathrm{W}\right) .6(10)$ : The northern shore of the Foryd estuary near Caernarfon $\left(53.131581^{\circ} \mathrm{N}, 4.304016^{\circ} \mathrm{W}\right)$. 7(5): Culzean Bay $\left(55.377332^{\circ} \mathrm{N}, 4.771487^{\circ} \mathrm{W}\right)$ 
Le Cam et al., 2015). This strong genetic similarity suggests that $S$. muticum has spread from a single point of invasion throughout the British coastline in a progressive manner (Mineur et al., 2010; Fig. 1). The morphologies of selected sites were broadly similar and the mesoscale positions of $S$. muticum stands were alike, since $S$. muticum's tolerance of wave-exposure is minimal (Davison, 2009). Populations were all shallow subtidal (0.5-1.3 $\mathrm{m}$ above chart datum), and in the lee of rock formations or sand-bars. Sargassum muticum stands were always amongst or nearby to common native algae such as Fucus serratus, Ascophyllum nodosum, $F$. vesiculosus and $F$. spiralis, and usually stands of Laminaria digitata, L. hyperborea and/or Sacharina latissima were observed within $50 \mathrm{~m}$ of the sample site.

Most of these locations are within 1 degree of latitude (Fig. 1), although the Foryd Estuary, 6(10) (for description of the naming convention see Fig. 1 caption), and Culzean bay, 7(5), were $3^{\circ}$ and $5^{\circ}$ further north respectively than the most southerly site of Exmouth, 4(35). Therefore, they differed in terms of average annual temperature and UV radiation levels. Sea temperatures at Exmouth were around $2{ }^{\circ} \mathrm{C}$ higher than at Culzean Bay at time of sampling, and total solar irradiance would have differed by approximately $200 \mathrm{kWh} / \mathrm{m}^{2}$ annually (estimated from the Photovoltaic Geographic Information System, Súri et al., 2007). The UV fraction is known to account for around $4 \%$ of total solar irradiance depending on humidity and cloud levels, giving an approximate difference of around 1.2\% UV between Exmouth and Culzean Bay (Escobedo et al., 2009). Temperature is not known to influence phlorotannin abundance, although it may increase the feeding rate of mesoherbivores. However, UV radiation has been shown to induce phlorotannin production in brown algae during laboratory trials (Pavia et al., 1998). Assuming a similar induction in $S$. muticum to that reported for the closely-related fucoid A. nodosum, a $1.2 \%$ increase in UV levels would equate to a $0.72 \%$ higher phlorotannin production at the southernmost site compared to the northernmost, a negligible difference considering that herbivory can increase phlorotannin abundance by over 70\% (Pavia $\&$ Toth, 2000). Other investigations into UV exposure on phlorotannins in brown algae have revealed no response (Henry \& Van Alstyne, 2004; Macaya et al., 2005), or variable responses depending on season and time-since-exposure (Gomez \& Huovinen, 2010;
Cruces et al., 2013) and there is some indication that whilst UVA induces phlorotannin production, UVB degrades the compounds (Swanson \& Druehl, 2002).

\section{Phlorotannin abundance}

Twenty-four S. muticum individuals were selected at random from each site in mid-summer (July), and vegetative tissues removed from the upper $20 \mathrm{~cm}$ of the frond where growth is recent $(n=24, N=168)$. The epiphyte loading differed between fronds, but rarely between individuals. Care was taken to select fronds free of epiphytes from any given individual, since their removal was impossible without damaging fronds. Separately, the holdfasts (discerned as per Norton, 1977) of 20 further individuals were sampled in the same fashion ( $n=20, N=140)$, although the tougher nature of these tissues allowed those bearing epiphytes to be sampled (epiphytes were removed by hand in the laboratory). Samples were kept refrigerated at $5{ }^{\circ} \mathrm{C}$ in a mobile chiller during transit to avoid degeneration.

For both the frond and holdfast material, several centimetres of clean sample were washed thoroughly with distilled water, freeze-dried to constant mass, ground until homogenous and analysed for phlorotannin abundance. $60 \%$ aqueous acetone was used as a solvent, and phlorotannins were extracted over $1 \mathrm{~h}$ under constant agitation in the dark. The algal pulp was separated from the supernatant by centrifugation (5300 rpm for $10 \mathrm{~min}$ ) and the acetone removed from this using in-vacuo cold-distillation in the dark $\left(80 \mathrm{kPa}, 38{ }^{\circ} \mathrm{C}\right.$ ) until only the $40 \%$ aqueous fraction remained (typically $\sim 2 \mathrm{~h}$ ). This was then diluted, filtered so as to remove precipitated lipophilic compounds (Pavia \& Toth, 2000) and analysed by photometry using a variation of the Folin-Ciocalteu method, with phloroglucinol (1,3,5-trihydroxybenzene, Sigma-Aldrich P3502) as a standard (Pavia \& Toth, 2000). The quantity of material collected from each sample was sufficient for multiple assays; six samples of both frond and holdfast materials were selected from each site to be analysed in triplicate, to determine the consistency of the phlorotannin extraction methodology. These were never more than 0.1 standard deviations from their respective means, indicating that the laboratory methodology was accurate and repeatable. 
Mesoherbivore survey

From each site, 20 S. muticum individuals were selected at random during the same tide as phlorotannin surveys and sampled for associated fauna by placing a bag over the whole alga in situ at low tide $(n=140)$. The entire individual, including the holdfast, was removed, measured to the nearest $0.5 \mathrm{~cm}$ and returned to the laboratory before being frozen at $-20{ }^{\circ} \mathrm{C}$ to fix any associated fauna.

Fauna were separated from the algae by washing the whole macrophyte over a $1 \mathrm{~mm}$ sieve, and through careful visual inspection of the fronds, stipe, and holdfast. The resulting fauna were identified to species level, and those known to feed on algal tissue were weighed ( $\pm 0.01 \mathrm{mg}$ wet-mass), and shell/body length measured $( \pm 0.1 \mathrm{~mm})$. Variation in length and mass of herbivore conspecifics between and within sites was minimal. Dry masses of each grazer were estimated by species and by site, as per Ricciardi \& Bourget (1998); allowing for the calculation of mesoherbivore dry mass per metre of $S$. muticum length. Ideally, dry mass of algae or at the very least an estimation of 'algal volume' (see Åberg, 1990) is preferred. However, almost all S. muticum individuals bore at least some fronds host to epiphytes, the most abundant being Ectocarpus spp. Removing this filamentous alga without causing substantial damage to the feathery $S$. muticum fronds was not possible. Whilst some individuals were 'bushier' than others, most were of a consistent morphology-likely a consequence of growing under similar levels of exposure (Baer \& Stengel, 2010). Furthermore, there is a very close relationship between length and weight in S. muticum ( $r=0.89$ in Wernberg et al., 2001; $r=0.94$ in Baer \& Stengel, 2010), which makes using length a reasonable proxy for 'size'. Only species known to be herbivores of macrophytes were included in the analysis. Lacuna vincta were excluded from analysis because they were juveniles, which feed on sediment (Fretter \& Manly, 1977).

Five different species diversity indices were calculated, since drawing conclusions from one alone is inadvisable (see Boyle et al., 1990). Simpson's diversity Index (1-D) measures the probability that two randomly selected individuals will belong to the same species. Margalef's diversity index (natural log) shows the number of species present, controlled for sampling effort. Pielou's evenness index (natural log) quantifies how similar the abundance of each species are to one another. The Shannon-Weiner Index (natural $\log$ ) is the ratio of species number to their relative importance within the sample. The Brillouin's index (natural $\log$ ) is functionally similar to the Shannon-Weiner index, but accounts for non-random sampling, possibly caused in this case by the differences in motility between species, which could have resulted in fewer highly-motile crustacea being sampled.

\section{Statistical analyses}

All data were tested for normality and homogeneity of variance by Anderson-Darling and Levene's tests respectively. Frond lengths, length-standardised mesoherbivore abundances, frond phlorotannin abundance and species diversity indices for associated mesoherbivores were analysed with one-way analysis of variance (ANOVA) with 'site' as the independent factor, and means were compared with Tukey's post hoc analyses. Total mesoherbivore abundances, and phlorotannin abundances in the fronds and holdfasts did not satisfy the assumption of homogeneity of variance, and so were analysed with Welch's ANOVA with 'site' as the independent factor, and means were compared with Games-Howell post hoc tests. Regression analyses were used to test for relationships between mesoherbivore abundance and frond length, and both length-standardised mesoherbivore biomasses and species diversity indices, with phlorotannin abundances in the fronds and holdfasts at each site. Due to the destructive nature of sampling, these relationships were tested at the site level $(n=7)$, comparing the site means of each independent variable as simultaneous collection of responses were not possible (i.e. the treatment of individuals for faunal abundance precluded the treatment of individuals for phlorotannin analysis). Statistical analyses were undertaken using Mintab 17@.

\section{Results}

Phlorotannin abundance with time-since-invasion

Phlorotannin abundances differed between populations in both the fronds (One-way ANOVA, SS = 93.86, $F_{6,161}=67.59, P<0.001$; Fig. $\left.2 \mathrm{a}\right)$ and the 
holdfasts (Welch's ANOVA, $\mathrm{F}_{6}, \quad 58=14.46$, $P<0.001$; Fig. 2b) of $S$. muticum. However, there was no evident trend with time-since-invasion (Fig. 2). With all sites pooled there was significantly more phlorotannin present in the holdfasts $(4.62 \%$ DM, S.E. $=0.13$ ) of $S$. muticum than in the fronds (3.96\% DM, S.E. $=0.07$ ) (Welch's ANOVA, $\left.F_{1,211}=12.49, P=0.001\right)$, although when comparing within sites this was only significant at site 5(19) (for description of the naming convention see Fig. 1 caption) (Welch's ANOVA, $F_{1,}{ }_{42}=38.68$, $P<0.001$ ), and reversed at site 3(35) (One-way ANOVA, SS $\left.=14.69, F_{1,42}=30.96, P<0.001\right)$.

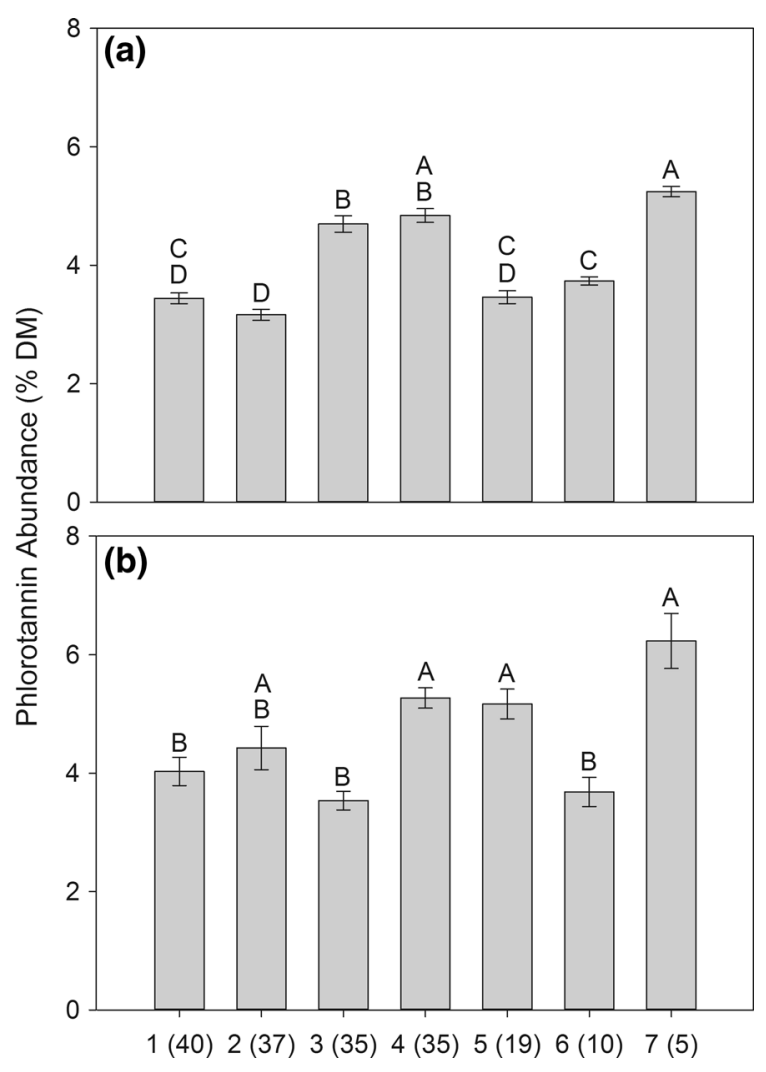

Fig. 2 Phlorotannin abundance (\% DM) in the upper fronds of Sargassum muticum $(\mathbf{a}, N=168)$ and holdfasts $(\mathbf{b}, N=140)$ of Sargassum muticum collected from seven populations around the British Isles. Grouping letters based on Tukey's (a) and Games-Howell post hoc (b) analysis; populations that do not share a letter are significantly different at $P<0.05$
Fig. 3 The abundance of adult mesoherbivores $(>1 \mathrm{~mm})$ per metre of frond length, collected from whole Sargassum muticum individuals $(N=140)$ from seven sites around the British Isles, a Littorina fabalis, b Idotea granulosa, c Idotea balthica, d Gammarus locusta, e Rissoa parva, f Ampithoe rubricata, $\mathbf{g}$ Dynamene bidentate, $\mathbf{h}$ all grazers. Sites are named in rank order of their time-since-invasion of S. muticum (years in parentheses)

Phlorotannin abundance with grazers

A large variety of animals were found on S. muticum fronds from all sites, including multiple species of caprellids, prawns, fish and juvenile mussels (Mytilus spp.) (Online Resource 1, Table ESM1). Holdfasts were often epiphytised by other seaweeds, including Ulva spp., Chondrus crispus and Fucus serratus recruits. Anemones, bryozoans and tunicates were also common on these perennial structures, whereas the annual fronds were epiphytised by Ectocarpus spp. almost exclusively. Nearly all individuals bore at least some fronds host to extensive amounts of Ectocarpus spp., and whilst quantifying it was not logistically viable, visual observation did not indicate any variability between or within sites.

Seven species of mesoherbivores were found on $S$. muticum, and their total biomass (herbivore DM) displayed a weak linear relationship with $S$. muticum length (Regression, $r^{2}=7.51 \%, P=0.001$ ). Abundances of most species differed greatly between sites (Fig. 3), and algae from 1(40) hosted more individual grazers overall than those from other sites (Welch's ANOVA, $F_{6,58}=40.95, P<0.001$; Fig. 3 h). However, algae from four of the seven sites bore host to every species of mesoherbivore found elsewhere and Gammarus locusta (Fig. 3d) was present in similar abundances at all sites (One-way ANOVA, SS = $\left.149.8, \quad F_{6}, 133=1.62, P=0.146\right)$. Within-species sizes of individuals did not differ between sites, and their average lengths were often smaller than that reported to be typical for their species (Table 1).

There was no relationship between the biomass of mesoherbivores on S. muticum fronds (estimated AFDM of mesoherbivores per unit length) and the mean phlorotannin abundance of holdfast or frond tissues (Online Resource 1, Table ESM2). In fact, $S$. muticum from all populations except the oldest, 1(40), hosted similar biomasses of mesoherbivores per unit frond length (One-way ANOVA, SS $=80.75$, 

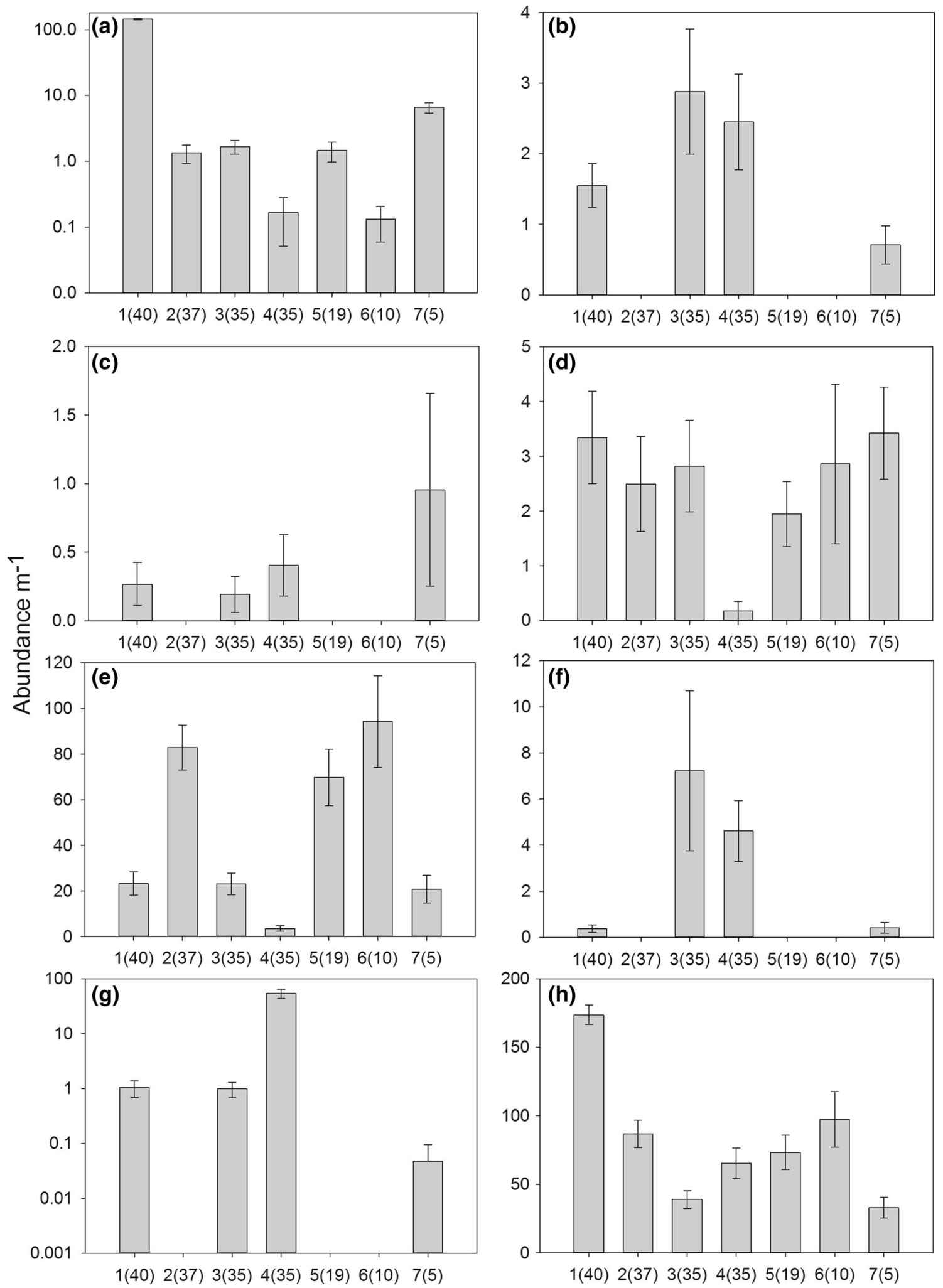
Table 1 Comparison of typical adult body lengths for mesoherbivores found on Sargassum muticum

\begin{tabular}{lll}
\hline Species & $\begin{array}{l}\text { Typical } \\
\text { adult length } \\
(\mathrm{mm})\end{array}$ & $\begin{array}{l}\text { Mean Length } \\
\text { on Sargassum } \\
\text { muticum }(\mathrm{mm}) \\
\text { and S.E }\end{array}$ \\
\hline Littorina fabalis & $<11$ & $5(0.02)$ \\
Idotea granulosa & $5-17$ & $7(0.10)$ \\
Idotea balthica & $10-25$ & $8(0.30)$ \\
Gammarus locusta & 33 & $4(0.06)$ \\
Rissoa parva & $<5$ & $3(0.01)$ \\
Ampithoe rubricata & 20 & $4(0.04)$ \\
Dynamene & $<7$ & $5(0.05)$ \\
bidentata & &
\end{tabular}

Typical lengths are taken from Hayward and Ryland (1995), and where applicable male and female lengths have been averaged. Hayward P. J., \& J. S. Ryland, 1995. Handbook of the marine fauna of North-West Europe. Oxford University Press, Oxford

$F_{6,133}=239.79, P<0.001$; Tukey's post hoc analysis

$1(40)>2(37)=3(35)=4(35)=5(19)=6(10)=7-$ (5). This difference was entirely due to the high abundances of Littorina fabalis on the fronds of 1(40) algae, which averaged $\sim 150$ individuals $\mathrm{m}^{-1}$ (Fig. 3a). Likewise, there was no relationship between the biomass of the three observed clades of grazers (gastropods, isopods and amphipods) and mean phlorotannin abundance in either the fronds or holdfast tissues of S. muticum (Online Resource 1, Table ESM2). Finally there was no relationship between the total number of mesoherbivore individuals and either the frond or holdfast phlorotannin abundance (Online Resource 1, Table ESM2).
All but one of the five tested diversity indices positively correlated with known frond phlorotannin abundances from the S. muticum populations (Table 2; Online Resource 1, Figure ESM4), with the commonly-used Simpson's Diversity Index showing a clear relationship (Fig. 4). The seven sites formed two distinct clusters, with sites 3(35), 4(35) and 7(5) noticeably higher on both axes than the other four. These three sites shared no specific commonalities not also present in the other four to explain this clustering. Only Margelef's Species Richness Index displayed no relationship with phlorotannin abundance $(P=0.051$, Table 2; Online Resource 1, Figure ESM4a). Conversely, mesoherbivore diversity did not correlate with abundances of phlorotannin in the holdfasts of $S$. muticum and no species diversity index displayed a relationship with time-since-invasion (Online Resource 1, Table ESM3).

\section{Discussion}

Phlorotannin abundances in the fronds of Sargassum muticum were positively dependent on the diversity of grazers in its stand. Although phlorotannins are found in many fucoids, the abundances observed in $S$. muticum were particularly high; comparable to those found in the highly grazer-resistant Ascophyllum nodosum (Pavia \& Toth, 2000; Kurr \& Davies, 2017b). Pronounced invasion success has been attributed to chemical defences in other species of algae (Forslund et al., 2010; Enge et al., 2012; Nylund et al., 2012; Svensson et al., 2013) and plants (Van Kleunen \& Schmid, 2003; Leger \& Forister, 2005; Huang et al., 2010; Lind \& Parker, 2010), and may

$20 \mathrm{~cm}$ of $S$. muticum frond material from those same sites $(n=7) . P$-values in bold are those significant at an $\alpha$-level of 0.05
Table 2 Regression analysis of relationships between five species diversity indices, for mesoherbivores found on the fronds of Sargassum muticum from seven sites around the British Isles, and phlorotannin abundance from the upper

\begin{tabular}{lllllrr}
\hline & Slope & Intercept & MS & $R^{2}$ & $F$ & $P$ \\
\hline Margelef's SR & 0.327 & -0.746 & 0.4353 & 56.46 & 6.48 & 0.051 \\
Pielou's evenness & 0.200 & -0.368 & 0.16193 & 80.07 & 20.09 & $\mathbf{0 . 0 0 7}$ \\
Shannon-Weiner & 0.338 & -0.890 & 0.4632 & 63.57 & 8.73 & $\mathbf{0 . 0 3 2}$ \\
Simpson's index & 0.201 & -0.541 & 0.16474 & 70.81 & $\mathbf{0 . 0 1 8}$ \\
Brillouin's index & 0.270 & -0.687 & 0.2961 & 59.69 & 7.40 & $\mathbf{0 . 0 4 2}$ \\
\hline
\end{tabular}




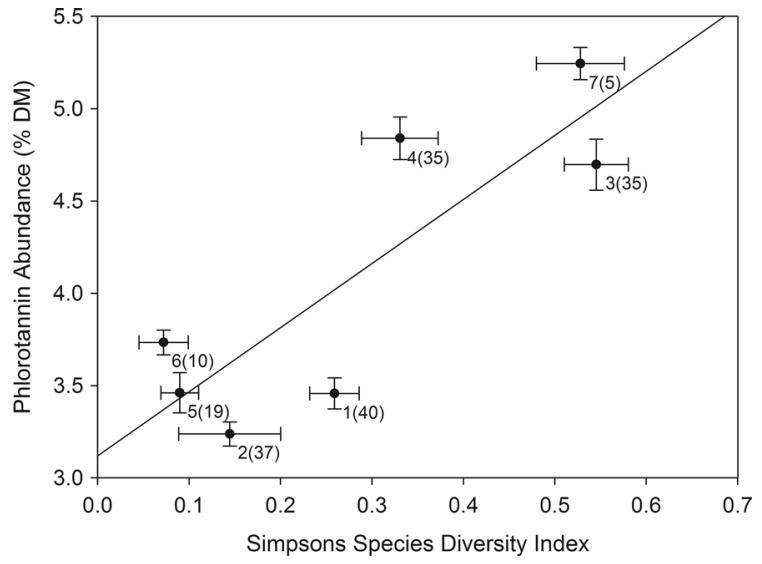

Fig. 4 The relationship between the Simpson's species diversity index for the mesoherbivores collected from the fronds of Sargassum muticum growing in seven different populations around the British Isles (reported time-since-invasion in parentheses), and the mean phlorotannin abundance (\% DM) in the fronds of $S$. muticum from those sites $(N=7)$. Error bars show standard error ( $X$ axis $n=20$ per site, $Y$-axis $n=24$ per site)

also explain the success of $S$. muticum outside of its native range (Engelen et al., 2015).

Although a large body of evidence suggests that a high diversity of native plants often affords better resistance to invasions by controphics (see Theoharides \& Dukes, 2007), surprisingly few studies have investigated the diversity of native enemies on the topdown-pressure experienced by invasive species (Maron \& Vilá, 2001; Agrawal \& Kotanen, 2003). One potential mechanism that could explain the patterns observed in this study is the 'sampling effect'. The greater the native species diversity, the greater the chance that some species are present that can outcompete or consume the non-native (e.g. Hooper et al., 2005), reducing the chance of complete enemy release. This effect has been observed in terrestrial plants, whereby enemy release becomes less likely when the native community contains multiple enemy guilds (e.g. insect herbivores, mammalian herbivores, parasites etc., see Agrawal et al., 2005).

In this study, most herbivores found on S. muticum were smaller than their typical adult size outside the canopy (see also Viejo, 1999; Strong et al., 2006). Young and/or competitively inferior individuals often prioritise shelter over food (e.g. Boström \& Mattila, 1999; Tait \& Hovel, 2012) to avoid predators, such as Palaemon serratus which were abundant in most stands of $S$. muticum in this study. If many grazer species found on S. muticum are not feeding on it, but are instead using it for shelter (Machado et al., 2015) or feeding solely on its epiphytes (Viejo, 1999; Cacabelos et al., 2010b) this would explain why the 'sampling effect' applies in this instance. Due to their small size, the probability that the individuals of any one grazer species were feeding directly on S. muticum tissues is likely much lower than if these individuals were adults. No specific faunal species, or faunal clades (gastropods/isopods/amphipods), were found exclusively or in unusual densities at the three stands with the highest frond phlorotannin abundances. Nor were there any relationships between biomasses of grazers in the three clades and phlorotannin abundance. This suggests that different species may be responsible for top-down-pressure at each site, and strengthens the argument that enemy diversity determined top-down pressure, rather than the common presence of a specific grazing species or clade.

Nutrient levels may have differed between sites, and there is evidence to suggest that water chemistry may influence phlorotannin abundance in some brown algae (e.g. Nitrates, Nitrites, Phosphates-Jormalainen et al., 2003), although this is not always the case (Copper-Toth \& Pavia, 2000; NitrogenToth et al., 2007). As with UV, shifts in phlorotannin levels due to nutrients have not been assessed for $S$. muticum, but shifts in other brown algae are typically no more than $\sim 5-10 \%$ (Jormalainen et al., 2003). There is also some evidence that nutrient levels, particularly Nitrogen levels, may suppress defence induction (Svensson et al., 2007) or cause a quicker reduction in phlorotannin abundance post-induction (Hemmi et al., 2004), but only when nutrient levels are unrealistically high (up to 8 times ambient in Hemmi et al., 2004; see Discussion in Svensson et al., 2007). As such, the most important drivers for differences in phlorotannin abundance were highly likely to be the grazers.

No effect of time-since-invasion on phlorotannin abundance was observed. Very limited data exist on chemical defences of invasive plants and algae with respect to time-since-invasion, but studies using leaf damage as a proxy for top-down pressure are often contradictory. Some show increased top-down pressure with time (e.g. Harvey et al., 2013) whilst others show no relationship (e.g. Carpenter \& Cappuccino, 2005). Although space-for-time substitution is widely 
used and generally applicable to many ecological studies (Blois et al., 2013), it is possible site-specific differences may have masked the impacts of timesince-invasion in this study. It is worth noting however, that phlorotannin abundances of around $4 \%$ dry mass were recorded previously from Bembridge Ledge (site 1(40)) when the time-since-invasion of $S$. muticum would have been only 5 years (Gorham \& Lewey, 1984). These levels are very similar to those found in this study at that site, and the methods used to determine them were identical. Therefore, there is no evidence to suggest that the interactions between native herbivores and S. muticum are changing with time.

Although differences were rarely significant at site level, holdfasts had a higher overall phlorotannin content than fronds when all individual algae were pooled, in accordance with one previous unpublished study (see Engelen et al., 2015). In contrast to the fronds, phlorotannin abundances in the holdfasts did not display any relationship with herbivore diversity. Little is known about the holdfasts of S. muticum, although these are usually the most important tissues in other macroalgae (Tugwell \& Branch, 1992; Pavia et al., 2002). Free-floating fronds are a valuable dispersal mechanism for S. muticum (Engelen et al., 2015), but detachment of the entire individual is likely undesirable and therefore defending these tissues against herbivory is vital. Because they are the only perennial part of S. muticum (Norton, 1977), the holdfasts probably have a different chemical ecology to the annual fronds. It was not feasible to directly assess differences in grazing activity between the fronds and holdfasts, but holdfasts are probably more susceptible to attack by a wider spectrum of grazers, particularly large mobile gastropods such as Littorina littorea which laid its eggs on the holdfasts at some sites. When heavily grazed, the fucoid Ascophyllum nodosum does not induce chemical defences on an asneeded basis, but instead maintains a high constitutive (Pavia \& Toth, 2008) level of defence which does not change with top-down pressure (Long et al., 2013). This may explain why the overall better-defended holdfasts did not display the same reaction to increased grazer diversity as the fronds.

Sargassum muticum is a very effective invader of many temperate coasts, and its distribution and success appear to be heavily dependent on abiotic factors such as wave-exposure (Davison, 2009). It is very difficult to determine the relative impacts of grazing on $S$. muticum, because comparisons of abundance and biomass between sites will always be confounded by wave-exposure, light levels, site topography and tidal-range. As such these results provide only limited insight into the dynamics of the S. muticum invasion, but they clearly demonstrate that even the most successful invader requires defence against attack. If the tissues lost to grazing were expendable or replaceable through rapid growth, expensive chemical defences would not be required (de Jong, 1995; Pavia \& Toth, 2008). Therefore, a high diversity of grazers is likely to have negative impacts on S. muticum's ability to grow and reproduce (Coley et al., 1985), and therefore to spread (Kimbro et al., 2013). This study highlights the need to consider grazer diversity in addition to grazer abundance when assessing top-down-pressure on a chemically-defended invasive plant or alga.

Acknowledgements The authors wish to thank Pete and Rebecca Muggeridge, as well as Harry and Amy Burgis, for the use and crewing of the yacht Fizzgig during sampling on the Isle of Wight. We also thank the staff and students of The School of Ocean Sciences, particularly Craig Robertson for help with mesoherbivore identification. This work was funded by a Natural Environment Research Council doctoral studentship awarded to M.K (NE/J500203/1). The authors declare that they have no conflict of interest.

Open Access This article is distributed under the terms of the Creative Commons Attribution 4.0 International License (http:// creativecommons.org/licenses/by/4.0/), which permits unrestricted use, distribution, and reproduction in any medium, provided you give appropriate credit to the original author(s) and the source, provide a link to the Creative Commons license, and indicate if changes were made.

\section{References}

Åberg, P., 1990. Measuring size and choosing category size for a transition matrix study of the seaweed Ascophyllum nodosum. Marine Ecology Progress Series 63: 281-287.

Agrawal, A. A. \& P. M. Kotanen, 2003. Herbivores and the success of exotic plants: a phylogenetically controlled experiment. Ecology Letters 6: 712-715.

Agrawal, A. A., P. M. Kotanen, C. E. Mitchell, A. G. Power, W. Godsoe \& J. Klironomos, 2005. Enemy release? An experiment with congeneric plant pairs and diverse aboveand belowground enemies. Ecology 86: 2979-2989.

Baer, J. \& D. B. Stengel, 2010. Variability in growth, development and reproduction of the non-native seaweed 
Sargassum muticum (Phaeophyceae) on the Irish west coast. Estuarine, Coastal and Shelf Science 90: 185-194.

Blois, J. L., J. W. Williams, M. C. Fitzpatrick, S. T. Jackson \& S. Ferrier, 2013. Space can substitute for time in predicting climate-change effects on biodiversity. Proceedings of the National Academy of Sciences 110: 9374-9379.

Boström, C. \& J. Mattila, 1999. The relative importance of food and shelter for seagrass-associated invertebrates: a latitudinal comparison of habitat choice by isopod grazers. Oecologia 120: 162-170.

Boyle, T. P., G. M. Smillie, J. C. Anderson \& D. R. Beeson, 1990. A sensitivity analysis of nine diversity and seven similarity indices. Research Journal Water Pollution Control Federation 62: 749-762.

Cacabelos, E., C. Olabarria, M. Incera \& J. S. Troncoso, 2010a. Do grazers prefer invasive seaweeds? Journal of Experimental Marine Biology and Ecology 393: 182-187.

Cacabelos, E., C. Olabarria, M. Incera \& J. S. Troncoso, 2010b. Effects of habitat structure and tidal height on epifaunal assemblages associated with macroalgae. Estuarine and Coastal Marine Science 89: 43-52.

Carpenter, D. \& N. Cappuccino, 2005. Herbivory, time since introduction and the invasiveness of exotic plants. Journal of Ecology 93: 315-321.

Coley, P. D., J. P. Bryant \& F. S. Chapin III, 1985. Resource availability and plant antiherbivore defense. Science 230 : 895-899.

Critchley, A. T., W. F. Farnham \& S. L. Morrell, 1983. A chronology of new European sites of attachment for the invasive brown alga, Sargassum muticum, 1973-1981. Journal of the Marine Biological Association United Kingdom 63: 799-811.

Critchley, A. T., W. F. Farnham \& S. L. Morrell, 1986. An account of the attempted control of an introduced marine alga, Sargassum muticum, in southern England. Biological Conservation 35: 313-332.

Cruces, E., P. Huovinen \& I. Gómez, 2013. Interactive effects of UV radiation and enhanced temperature on photosynthesis, phlorotannin induction and antioxidant activities of two sub-Antarctic brown algae. Marine biology 160: 1-13.

Davison, D. M., 2009. Sargassum muticum in Scotland 2008: a review of information, issues and implications. Scottish Natural Heritage Commissioned Report No.324. ROAME Number R07AC707.

Davies, A. J., M. P. Johnson \& C. A. Maggs, 2007. Limpet grazing and loss of Ascophyllum nodosum canopies on decadal time scales. Marine Ecology Progress Series 339: 131-141.

de Jong, T. J., 1995. Why fast-growing plants do not bother about defence. Oikos 74: 545-548.

Dijkstra, J. A., L. G. Harris, K. Mello, A. Litterer, C. Wells \& C. Ware, 2017. Invasive seaweeds transform habitat structure and increase biodiversity of associated species. Journal of Ecology 105: 1668-1678.

Dostál, P., J. Müllerová, P. Pyšek, J. Pergl \& T. Klinerová, 2013. The impact of an invasive plant changes over time. Ecology Letters 16: 1277-1284.

Enge, S., G. M. Nylund, T. Harder \& H. Pavia, 2012. An exotic chemical weapon explains low herbivore damage in an invasive alga. Ecology 93: 2736-2745.
Enge, S., G. M. Nylund \& H. Pavia, 2013. Native generalist herbivores promote invasion of a chemically defended seaweed via refuge-mediated apparent competition. Ecology Letters 16: 487-492.

Engelen, A. H., N. Henriques, C. Monteiro \& R. Santos, 2011. Mesograzers prefer mostly native seaweeds over the invasive brown seaweed Sargassum muticum. Hydrobiologia 669: 157-165.

Engelen, A. H., A. L. Primo, T. Cruz \& R. Santos, 2013. Faunal differences between the invasive brown macroalga Sargassum muticum and competing native macroalgae. Biological Invasions 15: 171-183.

Engelen, A. H., A. Serebryakova, P. Ang, K. Britton-Simmons, F. Mineur, M. F. Pedersen, F. Arenas, C. Fernández, H. Steen, R. Svenson, H. Pavia, G. Toth, F. Viard \& R. Santos, 2015. Circumglobal invasion by the brown seaweed Sargassum muticum. Oceanography and Marine Biology: An Annual Review 53: 81-126.

Escobedo, J. F., E. N. Gomes, A. P. Oliveira \& J. Soares, 2009. Modelling hourly and daily fractions of UV, PAR and NIR to global solar radiation under various sky conditions at Botucatu, Brazil. Applied Energy 86: 299-309.

Forslund, H., S. A. Wikström \& H. Pavia, 2010. Higher resistance to herbivory in introduced compared to native populations of a seaweed. Oecologia 164: 833-840.

Fretter, V. \& R. Manly, 1977. Algal associations of Tricolia pullus, Lacuna vincta and Cerithiopsis tubercularis (Gastropoda) with special reference to the settlement of their larvae. Journal of the Marine Biological Association United Kingdom 57: 999-1017.

Gomez, I. \& P. Huovinen, 2010. Induction of phlorotannins during UV exposure mitigates inhibition of photosynthesis and DNA damage in the kelp Lessonia nigrescens. Photochemistry and Photobiology 86: 1056-1063.

Gorham, J. \& S. A. Lewey, 1984. Seasonal changes in the chemical composition of Sargassum muticum. Marine Biology 80: 103-107.

Hallas, P., 2012. Genetics and ecology of the invasive marine alga, Sargassum muticum within Wales, PhD Thesis, University of Glamorgan.

Harvey, K. J., D. A. Nipperess, D. R. Britton \& L. Hughes, 2013. Does time since introduction influence enemy release of an invasive weed? Oecologia 173: 493-506.

Hayward, P. J. \& J. S. Ryland, 1995. Handbook of the marine fauna of North-West Europe. Oxford University Press, Oxford.

Hemmi, A., T. Honkanen \& V. Jormalainen, 2004. Inducible resistance to herbivory in Fucus vesiculosus duration, spreading and variation with nutrient availability. Marine Ecology Progress Series 273: 109-120.

Henry, B. E. \& K. L. Van Alstyne, 2004. Effects of UV radiation on growth and phlorotannins in Fucus Gardneri (Phaeophyceae) juveniles and embryos. Journal of Phycology 40: 527-533.

Hooper, D. U., F. S. Chapin, J. J. Ewel, A. Hector, P. Inchausti, S. Lavorel, J. H. Lawton, D. M. Lodge, M. Loreau, S. Naeem, B. Schmid, H. Setala, A. J. Symstad, J. Vandermeer \& D. A. Wardle, 2005. Effects of biodiversity on ecosystem functioning: a consensus of current knowledge. Ecological Monographs 75: 3-35. 
Huang, W., E. Siemann, G. S. Wheeler, J. Zou, J. Carrillo \& J. Ding, 2010. Resource allocation to defence and growth are driven by different responses to generalist and specialist herbivory in an invasive plant. Journal of Ecology 98: 1157-1167.

Jormalainen, V., T. Honkanen, R. Koivikko \& J. Eränen, 2003. Induction of phlorotannin production in a brown alga: defense or resource dynamics? Oikos 103: 640-650.

Karez, R., S. Engelbert \& U. Sommer, 2000. 'Co-consumption' and 'protective coating': two new proposed effects of epiphytes on their macroalgal hosts in mesograzer-epiphyte-host interactions. Marine Ecology Progress Series 205: 85-93.

Keane, R. M. \& M. J. Crawley, 2002. Exotic plant invasions and the enemy release hypothesis. Trends in Ecology \& Evolution 17: 164-170.

Kimbro, D. L., B. S. Cheng \& E. D. Grosholz, 2013. Biotic resistance in marine environments. Ecology Letters 16: 821-833.

Kurr, M. \& A. J. Davies, 2017a. Time-since-invasion increases native mesoherbivore feeding rates on the invasive alga, Sargassum muticum (Yendo) Fensholt. Journal of the Marine Biological Association of the United Kingdom 98: $1-10$.

Kurr, M. \& A. J. Davies, 2017b. Sex-specific reproductive tradeoffs in the gregarious fucoid macroalga Ascophyllum nodosum. European Journal of Phycology 53: 1-13.

Lankau, R. A., 2007. Specialist and generalist herbivores exert opposing selection on a chemical defense. New Phytologist 175: 176-184.

Le Cam, S., C. D. Thiebaut, S. Bouchemousse \& F. Viard, 2015. Elucidating unresolved invasion history with genome-wide sequencing approach: the case of the global invader Sargassum muticum. European Journal of Phycology 50: 24-25.

Leger, E. A. \& M. L. Forister, 2005. Increased resistance to generalist herbivores in invasive populations of the California poppy (Eschscholzia californica). Diversity and Distributions 11: 311-317.

Levine, J. M., 2000. Species diversity and biological invasions: relating local process to community pattern. Science 288 : 852-854.

Levine, J. M., P. B. Adler \& S. G. Yelenik, 2004. A metaanalysis of biotic resistance to exotic plant invasions. Ecology Letters 7: 975-989.

Lind, E. M. \& J. D. Parker, 2010. Novel weapons testing: are invasive plants more chemically defended than native plants? PLoS ONE 5: e10429.

Long, J. D., G. Toth \& H. Pavia, 2013. Proximate and ultimate causes for transatlantic variation in seaweed defenses. Marine Ecology Progress Series 493: 83-89.

Macaya, E. C., E. Rothäusler, M. Thiel, M. Molis \& M. Wahl, 2005. Induction of defenses and within-alga variation of palatability in two brown algae from the northern-central coast of Chile: effects of mesograzers and UV radiation. Journal of Experimental Marine Biology and Ecology 325: 214-227.

Machado, G. B. D. O., A. B. Neufeld, S. A. Dena, S. G. L. Siqueira \& F. P. P. Leite, 2015. Variation of amphipod assemblage along the Sargassum stenophyllum (Phaeophyta, Fucales) thallus. Nauplius 23: 73-78.
Maron, J. L. \& M. Vilá, 2001. When do herbivores affect plant invasion? Evidence for the natural enemies and biotic resistance hypotheses. Oikos 95: 361-373.

Mattila, J. M., M. Zimmer, O. Vesakoski \& V. Jormalainen, 2014. Habitat-specific gut microbiota of the marine herbivore Idotea balthica (Isopoda). Journal of Experimental Marine Biology and Ecology 455: 22-28.

Mineur, F., A. J. Davies, C. A. Maggs, M. Verlaque \& M. P. Johnson, 2010. Fronts, jumps and secondary introductions suggested as different invasion patterns in marine species, with an increase in spread rates over time. Proceedings of the Royal Society B 277: 2693-2701.

Monteiro, C. A., A. H. Engelen \& R. O. Santos, 2009. Macroand mesoherbivores prefer native seaweeds over the invasive brown seaweed Sargassum muticum: a potential regulating role on invasions. Marine Biology 156: 2505-2515.

Norton, T. A., 1977. Ecological experiments with Sargassum muticum. Journal of the Marine Biological Association of the United Kingdom 57: 33-43.

Norton, T. A. \& M. R. Benson, 1983. Ecological interactions between the brown seaweed Sargassum muticum and its associated fauna. Marine Biology 75: 169-177.

Nylund, G. M., R. T. Pereyra, H. L. Wood, K. Johannesson, \& H. Pavia, 2012. Increased resistance towards generalist herbivory in the new range of a habitat-forming seaweed. Ecosphere, 3, art125.

Pavia, H., G. Cervin, A. Lindgren \& P. Åberg, 1998. Effects of UV-B radiation and simulated herbivory on phlorotannins in the brown alga Ascophyllum nodosum. Marine Ecology Progress Series 157: 139-146.

Pavia, H., H. Carr \& P. Åberg, 1999. Habitat and feeding preferences of crustacean mesoherbivores inhabiting the brown seaweed Ascophyllum nodosum L. Le Jol. and its epiphytic macroalgae. Journal of Experimental Marine Biology and Ecology 236: 15-32.

Pavia, H. \& G. B. Toth, 2000. Inducible chemical resistance to herbivory in the brown seaweed Ascophyllum nodosum. Ecology 81: 3212-3225.

Pavia, H., G. B. Toth \& P. Åberg, 2002. Optimal defence theory, elasticity analysis as a tool to predict intraplant variation in defences. Ecology 83: 891-897.

Pavia, H. \& G. B. Toth, 2008. Macroalgal models in testing and extending defense theories. In Amsler, C. D. (ed.), Algal Chemical Ecology. Springer, Berlin: 147-172.

Pedersen, M. F., P. A. Stæhr, T. Wernberg \& M. S. Thomsen, 2005. Biomass dynamics of exotic Sargassum muticum and native Halidrys siliquosa in Limfjorden, Denmark-implications of species replacements on turnover rates. Aquatic Botany 83: 31-47.

Ricciardi, A. \& E. Bourget, 1998. Weight-to-weight conversion factors for marine benthic macroinvertebrates. Marine Ecology Progress Series 163: 245-251.

Rousseau, F., M. C. Leclerc \& B. De Reviers, 1997. Molecular phylogeny of European Fucales (Phaeophyceae) based on partial large-subunit rDNA sequence comparisons. Phycologia 36: 438-446.

Saul, W. C., J. M. Jeschke \& T. Heger, 2013. The role of ecoevolutionary experience in invasion success. NeoBiota 17: 57-74. 
Saul, W. C. \& J. M. Jeschke, 2015. Eco-evolutionary experience in novel species interactions. Ecology Letters 18: 236-245.

Schwartz, N., S. Rohde, S. Hiromori \& P. J. Schupp, 2016. Understanding the invasion success of Sargassum muticum: herbivore preferences for native and invasive Sargassum spp. Marine Biology 163: 181.

Smith-Ramesh, L. M., A. C. Moore \& O. J. Schmitz, 2017. Global synthesis suggests that food web connectance correlates to invasion resistance. Global Change Biology 23: 465-473.

Sotka, E. E., 2005. Local adaptation in host use among marine invertebrates. Ecology Letters 8: 448-459.

Strayer, D. L., V. T. Eviner, J. M. Jeschke \& M. L. Pace, 2006. Understanding the long-term effects of species invasions. Trends in Ecology \& Evolution 21: 645-651.

Stohlgren, T. J., D. Binkley, G. W. Chong, M. A. Kalkhan, L. D. Schell, K. A. Bull, Y. Otsuki, G. Newman, M. Bashkin \& Y. Son, 1999. Exotic plant species invade hot spots of native plant diversity. Ecological Monographs 69: 25-46.

Strong, J. A., M. J. Dring \& C. A. Maggs, 2006. Colonisation and modification of soft substratum habitats by the invasive macroalga Sargassum muticum. Marine Ecology Progress Series 321: 87-97.

Strong, J. A., C. A. Maggs \& M. P. Johnson, 2009. The extent of grazing release from epiphytism for Sargassum muticum (Phaeophyceae) within the invaded range. Journal of the Marine Biological Association United Kingdom 89: 303-314.

Sun, Y., H. Müller-Schärer, J. L. Maron \& U. Schaffner, 2015. Biogeographic effects on early establishment of an invasive alien plant. American Journal of Botany 102: 621-625.

Š́ri, M., T. A. Huld \& E. D. Dunlop, 2007. Potential of solar electricity generation in the European Union member states and candidate countries. Solar Energy 81: 1295-1305.

Svensson, C. J., H. Pavia \& G. B. Toth, 2007. Do plant density, nutrient availability, and herbivore grazing interact to affect phlorotannin plasticity in the brown seaweed Ascophyllum nodosum? Marine Biology 151: 2177-2181.

Svensson, J. R., G. M. Nylund, G. Cervin, G. B. Toth \& H. Pavia, 2013. Novel chemical weapon of an exotic macroalga inhibits recruitment of native competitors in the invaded range. Journal of Ecology 101: 140-148.

Swanson, A. K. \& L. D. Druehl, 2002. Induction, exudation and the UV protective role of kelp phlorotannins. Aquatic Botany 73: 241-253.

Tait, K. J. \& K. A. Hovel, 2012. Do predation risk and food availability modify prey and mesopredator microhabitat selection in eelgrass (Zostera marina) habitat? Journal of Experimental Marine Biology and Ecology 426: 60-67.

Theoharides, K. A. \& J. S. Dukes, 2007. Plant invasion across space and time: factors affecting nonindigenous species success during four stages of invasion. New Phytologist 176: 256-273.

Thomas, C. D. \& G. Palmer, 2015. Non-native plants add to the British flora without negative consequences for native diversity. Proceedings of the National Academy of Sciences 112: 4387-4392.

Thomsen, M. S., T. Wernberg, P. A. Stæhr \& M. F. Pedersen, 2006. Spatio-temporal distribution patterns of the invasive macroalga Sargassum muticum within a Danish Sargassum-bed. Helgoland Marine Research 60: 50-58.

Toth, G. B., 2007. Screening for induced herbivore resistance in Swedish intertidal seaweeds. Marine Biology 151: 1597-1604.

Toth, G., \& H. Pavia, 2000. Lack of phlorotannin induction in the brown seaweed Ascophyllum nodosum in response to increased copper concentrations. Marine Ecology Progress Series 192: 119-126.

Toth, G. B., M. Karlsson \& H. Pavia, 2007. Mesoherbivores reduce net growth and induce chemical resistance in natural seaweed populations. Oecologia 152: 245-255.

Tugwell, S. \& G. M. Branch, 1992. Differential polyphenolic distribution among tissues in the kelps Ecklonia maxima, Laminaria pallida and Macrocystis angustifolia in relation to plant-defence theory. Journal of Experimental Marine Biology and Ecology 129: 219-230.

Van Alstyne, K. L. \& V. J. Paul, 1990. The biogeography of polyphenolic compounds in marine macroalgae: temperate brown algal defenses deter feeding by tropical herbivorous fishes. Oecologia 84: 158-163.

Van Kleunen, M. \& B. Schmid, 2003. No evidence for an evolutionary increased competitive ability in an invasive plant. Ecology 84: 2816-2823.

Veiga, P., M. Rubal \& I. Sousa-Pinto, 2014. Structural complexity of macroalgae influences epifaunal assemblages associated with native and invasive species. Marine Environmental Research 101: 115-123.

Veiga, P., A. C. Torres, C. Besteiro \& M. Rubal, 2018. Mollusc assemblages associated with invasive and native Sargassum species. Continental Shelf Research 161: 12-19.

Vesakoski, O., J. Rautanen, V. Jormalainen \& T. Ramsay, 2009. Divergence in host use ability of a marine herbivore from two habitat types. Journal of Evolutionary Biology 22: 1545-1555

Viejo, R. M., 1999. Mobile epifauna inhabiting the invasive Sargassum muticum and two local seaweeds in northern Spain. Aquatic Botany 64: 131-149.

Watson, D. C. \& T. A. Norton, 1987. The habitat and feeding preferences of Littorina obtusata (L.) and L. mariae Sacchi et Rastelli. Journal of Experimental Marine Biology and Ecology 112: 61-72.

Wernberg, T., M. S. Thomsen, P. A. Stæhr \& M. F. Pedersen, 2001. Comparative phenology of Sargassum muticum and Halidrys siliquosa (Phaeophyceae: Fucales) in Limfjorden, Denmark. Botanica Marina 44: 31-39.

Wernberg, T., M. S. Thomsen, P. A. Staehr \& M. F. Pedersen, 2004. Epibiota communities of the introduced and indigenous macroalgal relatives Sargassum muticum and Halidrys siliquosa in Limfjorden (Denmark). Helgoland Marine Research 58: 154-161.

Withers, R. G., W. F. Farnham, S. Lewey, N. A. Jephson, J. M. Haythorn \& P. W. G. Gray, 1975. The epibionts of Sargassum muticum in British waters. Marine Biology 31: 79-86.

Publisher's Note Springer Nature remains neutral with regard to jurisdictional claims in published maps and institutional affiliations. 